\title{
Bilateral substantia nigra lesions on magnetic resonance imaging in a patient with encephalitis lethargica
}

A 21 year old man was admitted to hospital presenting with low grade fever $\left(37.7^{\circ} \mathrm{C}\right)$, slight meningeal irritation, headache, visual hallucinations, dysarthria, insomnia, gait and limb ataxia, and a postural tremor.

There was no relevant history except for a fall into a river after a fight 2 weeks before admission. There were only a few superficial skin lesions, no medical attention was sought. The patient denied the use of recreational drugs.

Brain CT was normal. A lumbar puncture was performed showing 72 white blood cells $/ \mathrm{mm}^{3}$ ( $84 \%$ monocytes and $16 \%$ polymorphic neutrophils), and a normal protein $(34 \mathrm{mg} / \mathrm{dl}$, normal $<45 \mathrm{mg} / \mathrm{dl})$ and glucose content (70 mg/dl, in serum $100 \mathrm{mg} / \mathrm{dl}$ ). Bacterial, mycobacterial, and viral cultures were negative. Treatment with acyclovir and ceftriaxone was given and discontinued after 5 days, when the results of the cultures and polymerase chain reaction were normal.

Four days after admission, the neurological picture changed into a hypokinetic rigid syndrome with cogwheel rigidity, katatonia, akinetic mutism, dysphagia, and severe sialorrhoea and hyperhydrosis. A few oculogyric crises were noted. A clinical diagnosis of encephalitis lethargica was made, according to the criteria of Howard and Lees. ${ }^{1}$ Brain MRI showed bilateral hyperintense signals in the substantia nigra (fig 1) and also lesions in the right striatum (fig 2) and in the right frontal lobe on MRI FLAIR images.

A treatment with levodopa/benserazide and ropinirole was started on day 4 without benefit. The patient developed spasticity and anisocoria. On day 14 treatment was started with $1 \mathrm{~g}$ intravenous methylprednisolone daily during 5 days with only a slight improvement of his extrapiramidal symptoms. A more sustained amelioration

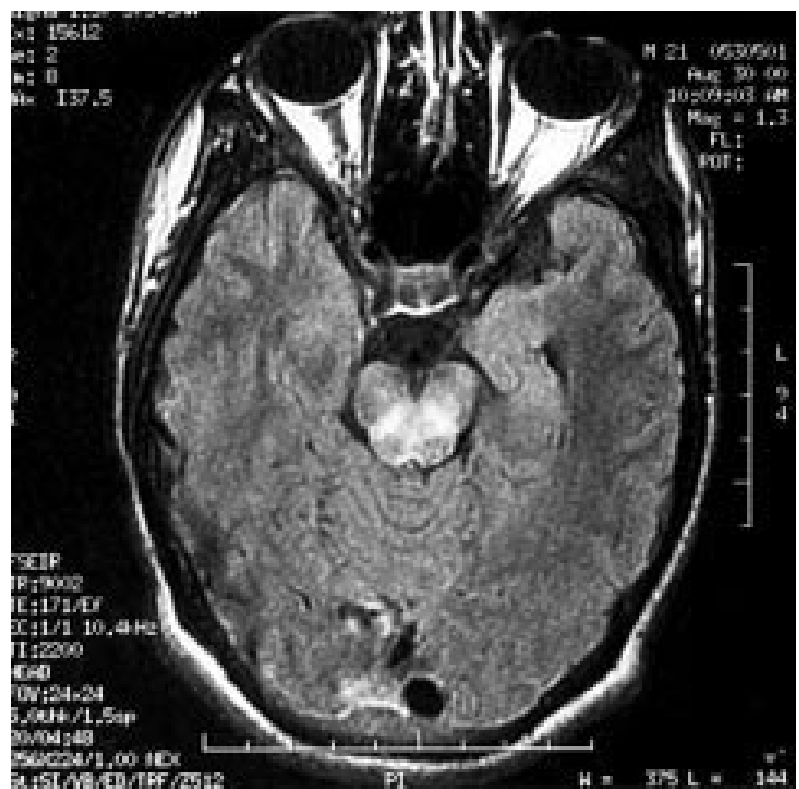

Figure 1 Bilateral hyperintense lesions of the substantia nigra on MRI flair image on day four. occurred after a second 5 day treatment with daily intravenous $1 \mathrm{~g}$ methylprednisolone, started on day 23 , followed by tapering.

A seroconversion was noted for Coxsackie virus type B3 (titre 0 on day $4,1 / 320$ on day 25). Other bacterial and viral serologies remained negative or unchanged. The substantia nigra lesions were less intense on a control brain MRI on day 50 .

At the latest follow up a slight extrapiramidal syndrome persists with an expressionless face, diminished blinking, a monotonous voice, slight cogwheel rigidity, diminished arm swing, a fast, irregular tremor of arms and lips, and excessive sweating.

The current treatment consists of $200 \mathrm{mg}$ levodopa/50 $\mathrm{mg}$ benserazide and $1 \mathrm{mg}$ ropinirole thrice daily.

As far as we know, this is only the second case of bilateral substantia nigra lesions on MRI in a patient with encephalitis lethargica. ${ }^{2}$

We thank Dr Manfred Van den Kerchove for his help in taking care of the patient and Dr Barbara Pickut for revising the text.

H VERSCHUEREN

Department of Neurology, Algemeen Ziekenhuis Monica, Campus OLV Middelares, Deurne, Belgium

R CROLS

Department of Neurology, Algemeen Ziekenhuis Middelheim, Antwerpen, Belgium

Dr R Crols, Algemeen Ziekenhuis Middelheim, Lindendreef 1, B-2020 Antwerpen, Belgium

Roeland.Crols@OCMW.Antwerpen.be

$$
\begin{aligned}
& 1 \text { Howard RS, Lees AJ. Encephalitis lethargica: a report of four recent cases. } \\
& \text { Brain 1987;110:19-35. } \\
& 2 \text { Kun LN, Yian SY, Haur LS, et al. Bilateral substantia nigra changes on MRI } \\
& \text { in a patient with encephalitis lethargica. Neurology 1999;53:1860-2. }
\end{aligned}
$$

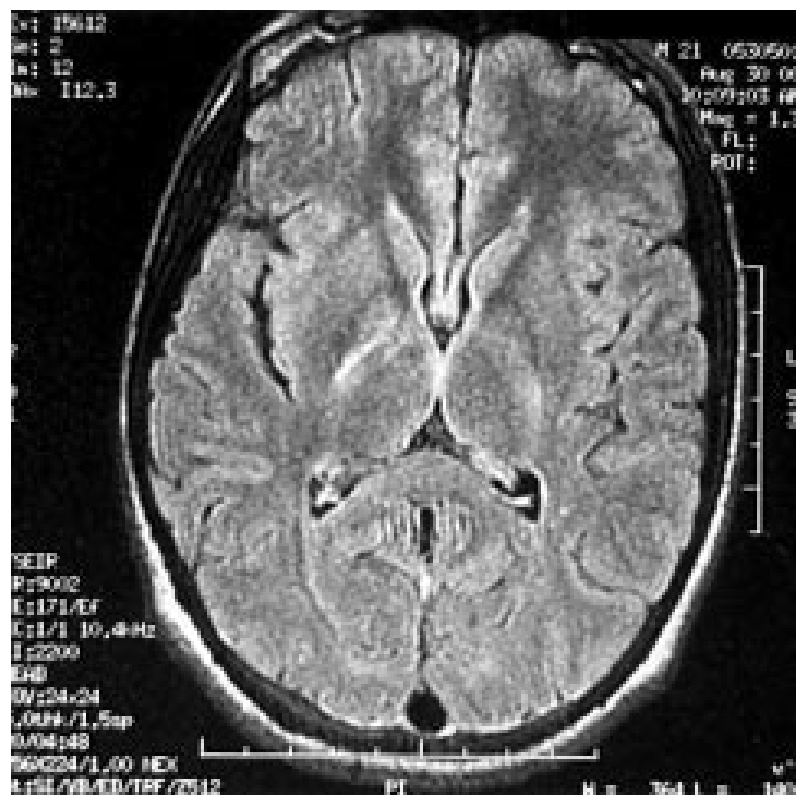

Figure 2 Hyperintense lesion of the right striatum on MRI flair image on day four. 